\title{
Molecular Characterisation of Soil-Dwelling Bacillus thuringiensis using Transcriptional Regulator, XRE Gene and the Crystal Protein, cry2 gene
}

\author{
Akinyelure, E. O. (D*, Machido, D. A. and Atta, H. I. \\ Department of Microbiology, Faculty of Life Sciences, Ahmadu Bello University, Zaria, Nigeria \\ *Corresponding Author's E-mail Address: akinyeluree@gmail.com
}

\begin{abstract}
Bacillus thuringiensis (Bt) is the organism that is used most frequently in biological pest management, which is distinguished by the capacity to possess crystalline inclusions throughout the sporulation phase. There is an increasing need to use biological control in controlling plant pathogens due to the inherent advantages. However, the detection of Bt has become more time consuming and cumbersome due to the numerous available crystal genes. The goal of the study was to isolate strains of Bacillus thuringiensis from the soil, characterise the isolates using the transcriptional regulator, XRE gene and the crystal proteins cry2gene and compare the efficiency of these two biomarkers in identifying Bt species. Five different Bacillus thuringiensis strains were isolated from soil samples in Zaria, Nigeria. Polymerase chain reaction was used to detect the existence of the cry2 and XRE genes. Four $(80 \%)$ of the five isolates harboured the XRE genes, while none $(0 \%)$ harboured the cry2 genes. This observation is a likely indication that the XRE gene is a reliable biomarker in the identification of Bt isolates from environmental samples. In order to ensure speed and reproducibility in the detection of Bt from environmental samples, molecular techniques targeting the XREgene are recommended.

Keywords: Bacillus thuringiensis; transcriptional regulator, XRE; crystal protein, cry2
\end{abstract}

\section{INTRODUCTION}

Bacillus thuringiensis $(\mathrm{Bt})$ is an aerobic, Grampositive rod-shaped soil bacterium found in diverse ecosystems around the world, including soil, water, warehouses particulates, woody and coniferous tree leaves, dead insects and insectivorous animals (Dharmender et al., 2008; Roh et al., 2017). It is well documented that during the sporulation process, it has the capacity to produce crystal inclusions (cry toxins) containing insecticidal proteins known as $\delta$-endotoxin (Schünemann et al., 2014). These endotoxins are specific to their targets; for instance, bipyramidal and cuboidal inclusions encoded by cry 1 , cry2, cry7, cry8, cry9, cry15, cry22 and cry51genes are effective towards Lepidoptera and Coleoptera insect pests (Frankenhuyzen, 2009; Jain et al., 2017). The spherical, composite, flat and other crystals inclusions are toxic to Diptera, Hemiptera, Hymenoptera, Hemiptera, Siphonoptera insects (Frankenhuyzen, 2009).

There are currently 78 known cry genes families with 823 distinct cry genes and 3 cyt families with 40 distinct cyt genes (Crickmore, 2020). Hence, the characterisation of Bacillus thuringiensis from environmental samples becomes even more time consuming and cumbersome using the currently available cry genes as biomarkers as cry protein products vary with the different categories of cry genes.
Using universal primers, the $16 \mathrm{~S}$ rRNA gene sequences showed high genetic relatedness between Bacillus thuringiensis and Bacillus cereus (Helgason, 2000; Rasko et al., 2005; Bartoszewicz and Marjanska, 2017). Furthermore, the characterization of Bt isolates with specific crystal toxins, becomes difficult when one considers that the genes encoding these various toxins are mostly borne on plasmids, which can be temporarily or permanently transferred to each other or to Bacillus cereus.(Rolle et al., 2005; Fiuza, 2015). To circumvent these limitations, the $X R E$ gene (that regulates the most common type of crystal protein production) was targeted to detect Bacillus thuringiensis (Wei et al., 2019). Wei et al. (2019)developed a real-time PCR method to explain the detection of Bacillus thuringiensis targeting the transcriptional regulator, XRE gene, in spiked food samples from South Korea. However, to the best of our knowledge, there has been no published work on the detection of $\mathrm{Bt}$ isolated from environmental samples targeting the XRE genes. The cry2 gene is one of the most common crystal genes used in characterizing Bacillus thuringiensis.

The transcriptional regulator, XRE gene has not been the focus of studies based on the identification of Bacillus thuringiensis in Nigeria. 
There is increased interest globally in the control of plant pathogens using biological agents such as Bacillus thuringiensis, molecular methods are, hence, important in the comprehensive identification of these agents. Nigeria is in dire need of more studies in this area of research as culture dependent techniques alone do not highlight key markers of this biocontrol agent (Bacillus thuringiensis). Therefore, in view of the highlighted concerns above, the current study was conducted to isolate Bacillus thuringiensis strains from various soil types in Zaria, Nigeria, and to compare the effectiveness of the XRE gene with that of the established crystal protein, cry2 gene in detecting the putative Bacillus thuringiensis isolates using PCR.

\section{MATERIALS AND METHODS}

\section{Collection of Soil Samples}

Soil samples were collected from fields of three sites in Zango, Zaria namely, Tomato farmland, Cow rangeland and Refuse dump site. Soil sample of $10 \mathrm{~g}$ was collected from the surface to a depth of 5 to $10 \mathrm{~cm}$ in each of ten spots within each site. The ten soil samples from each site were bulked and thoroughly mixed to obtain representative composite soil samples(Stefani et al., 2015).The soil samples from the three sites were stored in polythene bags and brought to the Environmental Research Laboratory, Department of Microbiology, Ahmadu Bello University, Zaria for isolation of Bacillus thuringiensis from the samples

\section{Isolation of Bacillus thuringiensis}

Bacillus thuringiensis were isolated using the sodium acetate selection method outlined by Travers et al. (1987) with some modifications. Ten grams soil was dissolved into $90 \mathrm{~mL}$ of distilled water and incubated for 45 mins at $28^{\circ} \mathrm{C}$ on a rotatory shaker (B. Bran scientific \& instrument company, England) at $250 \mathrm{rpm}$. Thereafter, $2 \mathrm{~mL}$ of the broth culture was added to $20 \mathrm{~mL}$ of sterile Luria Bertani (LB) (Tryptone $10 \mathrm{~g} / \mathrm{L}$, yeast extract $5 \mathrm{~g} / \mathrm{L}, \mathrm{NaCl}$ $5 \mathrm{~g} / \mathrm{L})$ broth buffered with $0.25 \mathrm{M}$ sodium acetate (pH 6.8) in $50 \mathrm{~mL}$ Erlenmeyer flask and incubated for 4 hours at $28^{\circ} \mathrm{C}$ on a rotatory shaker at $250 \mathrm{rpm}$. After incubation, $5 \mathrm{~mL}$ aliquots from each culture were placed in hot water bath operating at $80^{\circ} \mathrm{C}$ for 3 minutes. Thereafter, $0.1 \mathrm{~mL}$ was spread on LB agar (Tryptone $10 \mathrm{~g} / \mathrm{L}$, yeast extract $5 \mathrm{~g} / \mathrm{L}, \mathrm{NaCl} 5 \mathrm{~g} / \mathrm{L}$ and Agar $15 \mathrm{~g} / \mathrm{L}$ ) and incubated at $28^{\circ} \mathrm{C}$ for 24 hr.
Purification and Preservation of Typical Bacillus thuringiensis Isolates

Colonies having morphology typical of Bacillus thuringiensis (cream coloured, dry surface with entire margin) were selected and purified by subculturing on T3 agar (Tryptone $3 \mathrm{~g} / \mathrm{L}$, yeast extract $1.5 \mathrm{~g} / \mathrm{L}$, Peptone $2 \mathrm{~g} / \mathrm{L}$, Sodium phosphate $0.05 \mathrm{M}, \mathrm{MnCl}_{2} 0.005 \mathrm{~g} / \mathrm{L}$ and Agar $15 \mathrm{~g} / \mathrm{L}$ ) to obtain pure cultures and then preserved at $4^{\circ} \mathrm{C}$ for further studies.

\section{Biochemical Characterisation of Isolates}

The characteristic cultural and biochemical properties of the suspected Bacillus thuringiensis strains were determined following Gram staining and spore staining procedures (Bergey, 2004; Willey, 2008).Biochemical tests conducted include: motility, casein hydrolysis, oxidase, citrate utilization, Methyl red-Voges Proskaeur, catalase, and arginine hydrolysis.

Detection of cry2 gene and transcriptional regulator (XRE) gene

Qiagen DNA easy extraction kit (Jiangsu Mole Bioscience Co., Ltd, China) was used to extract DNA based on the manufacturer's instructions. The PCR conditions for the amplification of the cry2 and the XRE genes were performed as described by Ben-Dov et al. (1997) and Wei et al., (2019) respectively.

Polymerase chain reactions were carried out in $25 \mu \mathrm{L}$ reaction mixture containing $8 \mu \mathrm{L}$ template DNA, $150 \mathrm{mM}$ dNTPs, $20 \mathrm{pM}$ of each of the four primers (Table 1 ) and $0.5 \mathrm{U}$ of Taq DNA polymerase. The XRE gene was amplified in a DNA thermocycler using the following program: 1 initial denaturing cycle at $94^{\circ} \mathrm{C}$ for 3 minutes, 35 cycles containing: denaturing at $94^{\circ} \mathrm{C}$ for 30 seconds, annealing at $49^{\circ} \mathrm{C}$ for 30 seconds and extension for 30 seconds at $72^{\circ} \mathrm{C}$ and then the reaction being terminated by a final extension for 10 minutes at $72^{\circ} \mathrm{C}$. The amplification of the cry2 gene was carried out with the program: 1 initial denaturing cycle at $94^{\circ} \mathrm{C}$ for 3 minutes, 35 cycles containing: denaturing at $94^{\circ} \mathrm{C}$ for 30 seconds, annealing at $55^{\circ} \mathrm{C}$ for 30 seconds and extension for 1 minute at $72^{\circ} \mathrm{C}$, thereafter, a final extension for 10 minutes at $72^{\circ} \mathrm{C}$ to complete the reaction.

The XRE gene and the cry2gene bands were visualized using agarose gel electrophoresis. An aliquot $(15 \mu \mathrm{L})$ of the amplification products was loaded onto $1.5 \%$ agarose gel and runat 100volts for 1 hour in TAE buffer (40mM TrisAcetate, $1 \mathrm{mM}$ EDTA). The gels were stained with ethidium bromide and a molecular weight marker of $100 \mathrm{bp}$ was used to document them. 
Table 1. Primer sets used in the amplification of the cry2 and the XRE genes

\begin{tabular}{lllcl}
\hline Genes & Primer Sequence $\left(5^{\prime} \mathbf{3}^{\prime}\right)$ & $\begin{array}{c}\text { Product size } \\
\text { (bp) }\end{array}$ & Reference \\
\hline cry2 & F & GTTATTCTTAATGCAGATGAATGGG & 689 & Ben-Dov et al. (1997) \\
& $\mathrm{R}$ & CGGATAAAATAATCTGGGAAATAGT & & \\
& & & & Wei et al. (2019) \\
\hline
\end{tabular}

\section{RESULTS}

The colonial morphology, as well as the microscopic and biochemical characteristics of the isolates showing the expected characteristics of Bacillus thuringiensis are as shown in Table 2. Colonies that appeared creamy white, circular, dry, with flat elevation and wavy margin on LB agar were regarded putatively asBacillus thuringiensis.

Table 3 shows the frequency and percentage of isolates with the desired microscopic and biochemical characterization. The occurrence of Bacillus thuringiensis isolates from various soil types namely, agricultural farmlands, refuse dump site and cow rangeland, are as shown in Table 4.

The five isolates identified using cultural, microscopic and biochemical characterizations were tested for the presence of the cry2 andthe XRE genesby PCR. The amplicons of the $X R E$ gene $(246 \mathrm{bp})$ were detected in four of the strains of Bacillus thuringiensis (Plate I). In all of the strains, the cry2 gene (689 bp) was not amplified.

Table 2. Biochemical characterization of isolates Bacillus thuringiensis

\begin{tabular}{|c|c|c|c|c|c|}
\hline Isolate code & C1 & $\mathrm{C2}$ & $\mathrm{C6}$ & R3 & R4 \\
\hline $\begin{array}{l}{ }^{*} \text { Colonial } \\
\text { morphology }\end{array}$ & + & + & + & + & + \\
\hline $\begin{array}{l}\text { Gram } \\
\text { reaction/Shape } \\
\text { of cells }\end{array}$ & $+/ R$ & $+/ R$ & $+/ R$ & $+/ \mathrm{R}$ & $+/ R$ \\
\hline Chains of cells & + & + & + & + & + \\
\hline Endospore stain & + & + & + & + & + \\
\hline Motility & + & + & + & + & + \\
\hline Catalase & + & + & + & + & + \\
\hline Oxidase & + & + & + & + & + \\
\hline Methyl Red & - & - & - & - & - \\
\hline $\begin{array}{l}\text { Voges } \\
\text { Proskauer }\end{array}$ & + & + & + & + & + \\
\hline $\begin{array}{l}\text { Casein } \\
\text { hydrolysis }\end{array}$ & + & + & + & + & + \\
\hline $\begin{array}{l}\text { Arginine } \\
\text { hydrolysis }\end{array}$ & - & - & - & - & - \\
\hline $\begin{array}{l}\text { Utilization of } \\
\text { citrate }\end{array}$ & + & + & + & + & + \\
\hline Remark & $\mathrm{Bt}$ & $\mathrm{Bt}$ & $\mathrm{Bt}$ & $\mathrm{Bt}$ & $\mathrm{Bt}$ \\
\hline
\end{tabular}

$\mathrm{C} 1, \mathrm{C} 2$ and $\mathrm{C} 6$ = Isolates from Cow rangeland

R3 and R4 = Isolates from Refuse dump site

* = colonies that appear creamy white, circular, dry, flat elevation and with wavy margin on LB agar

$+=$ positive reaction. $-=$ negative reaction .

$\mathrm{R}=\operatorname{rod}$.

$\mathrm{Bt}=$ Bacillus thuringiensis. 
Table 3. Frequency and percentage of isolates with the desired microscopic and biochemical characteristics

\begin{tabular}{|c|c|c|c|}
\hline Test & $\begin{array}{l}\text { Result expected for Bacillus } \\
\text { thuringiensis }\end{array}$ & $\begin{array}{c}\text { Number of } \\
\text { isolates } \\
\text { tested }\end{array}$ & $\begin{array}{l}\text { Number with the } \\
\text { desired result (\%) }\end{array}$ \\
\hline Gram reaction & Gram positive & 16 & $13(81)$ \\
\hline Shape of cells & Rod shaped & 16 & $12(75)$ \\
\hline Chains of cells & Rods in chain & 16 & $11(69)$ \\
\hline Endospore stain & $\begin{array}{c}\text { Green spores with pink vegetative } \\
\text { tissue }\end{array}$ & 11 & $8(73)$ \\
\hline Motility & Motile organism & 8 & $8(100)$ \\
\hline Catalase & $\begin{array}{l}\text { Positive reaction (presence of } \\
\text { bubbles) }\end{array}$ & 5 & $5(100)$ \\
\hline Oxidase & Positive (purple colour) & 5 & $5(100)$ \\
\hline Methyl Red & Negative (No change in colour) & 5 & $5(100)$ \\
\hline Voges Proskauer & Positive reaction (Red colour) & 5 & $5(100)$ \\
\hline Casein hydrolysis & $\begin{array}{l}\text { Positive (production of halo zone } \\
\text { around the colony) }\end{array}$ & 5 & $5(100)$ \\
\hline Arginine hydrolysis & $\begin{array}{l}\text { Negative (No clear zone around the } \\
\text { colony) }\end{array}$ & 5 & $5(100)$ \\
\hline Utilization of citrate & $\begin{array}{c}\text { Positive (colour change from green to } \\
\text { blue) }\end{array}$ & 5 & $5(100)$ \\
\hline
\end{tabular}

Table 4. Frequency of distribution of Bacillus thuringiensis isolates in various soil types after biochemical characterization

\begin{tabular}{|c|c|c|c|c|}
\hline $\begin{array}{l}\text { Sources of soil } \\
\text { samples }\end{array}$ & $\begin{array}{c}\text { *Number of } \\
\text { Bacillus like } \\
\text { isolates }\end{array}$ & $\begin{array}{l}\text { Number of } \mathrm{Bt} \\
\text { isolates }\end{array}$ & ${ }^{\mathrm{a} B t}$ index & $\begin{array}{c}\text { Frequency of } \\
\text { distribution of } \mathrm{Bt} \\
(\%)\end{array}$ \\
\hline $\begin{array}{l}\text { Agricultural } \\
\text { farmland }\end{array}$ & 5 & 0 & 0.00 & $(0)$ \\
\hline Cow rangeland & 6 & 3 & 0.50 & (50) \\
\hline Refuse dump site & 5 & 2 & 0.40 & (40) \\
\hline Total & 16 & 5 & 0.31 & (31) \\
\hline
\end{tabular}

* Creamy white, circular, dry, flat elevation, with wavy margin

a Bt Index: Divide the number of Bacillus thuringiensis isolates by the total number of Bacillus-like colonies.

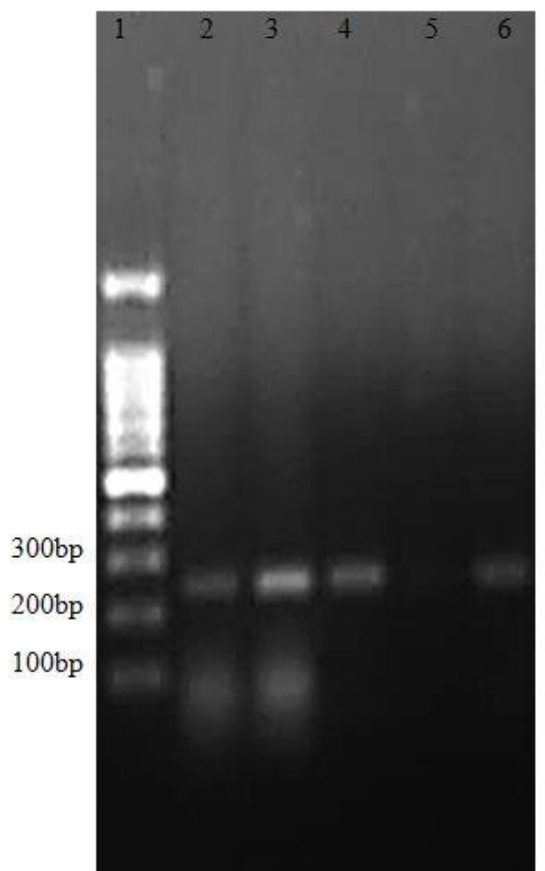

Plate I. Amplification of XRE gene (246 bp) in Bacillus thuringiensis isolated from soil samples Key: Lane 1: DNA ladder (100bp), Lanes 2 - 4: Bt isolated from Cow range (C1, C2, C6, respectively), Lanes 5 and 6: Bt isolated from Refuse dump (R3 and R4, respectively)

UMYU Journal of Microbiology Research $156 \quad$ www.ujmr.umyu.edu.ng 


\section{DISCUSSION}

An isolation procedure similar to the one used in this study was also utilised by Bello and Hussaini, (2017) and Adeyemo et al. (2018) and numerous Bacillus thuringiensis strains were isolated from different soil samples in Zaria and Okitipupa respectively.

The suspected Bacillus thuringiensis isolates were subjected to biochemical characterization and the observations made were in agreement to those reported by Kaur et al. (2002) and Eswarapriya et al. (2010)who reported that in addition to producing parasporal crystal bodies, the strains of Bacillus thuringiensis also have positive reactions for catalase production, citrate utilization, casein and starch hydrolysis. The estimated value of successful Bacillus thuringiensis isolation (Bt index) varies with types of soil, with 0.31 being the average $\mathrm{Bt}$ index observed in this present study. The average Bt index varies among soil samples across the globe, as previously reported (VilasBoas and Lemos, 2004; Lone et al., 2016; Lone et al., 2017). The possible cause of the variation in Bt index may be a consequence of the difference in topography, nutrient availability, humidity, isolation source, geography and the interaction between bacterium and pests which could significantly affect their populations in different habitats.

The higher frequency of Bacillus thuringiensis isolated from cow rangeland relative to refuse dump site and agricultural farmland could be attributed to the fact that this soil type likely has higher organic matter content which favours the growth and proliferation of Bacillus thuringiensis which naturally occur on saprophytic plants and nourishes on dead organic matter. This finding corroborates the study of Bello and Hussaini, (2017) where higher occurrence of Bacillus thuringiensis was observed in Cow rangeland soil type.

Owing to the speed and reproducibility of the PCR-based approach, it has been widely used since its introduction by Carozzi et al. (1991) for the detection of established and newcry genes in strains of Bacillus thuringiensis. For the five strains isolated in this study, the cry2 gene was not amplified, implying that the isolates have not acquired the plasmids harbouring the cry2 gene. It also indicates that the isolates may have other kinds of cry genes that were not targeted throughout the study; as the $B$. thuringiensis strain has been reported to harbour one or even more crystal toxin genes (Crickmore et al., 2011). The primary cause for toxin genes diversity could be attributed to the fact they are mostly expressed on plasmids which are easily transferred partially or completely among $B$. thuringiensis strains (Fiuza, 2015; Liu et al., 2015). This agrees with the reports of Bello and Hussaini (2017) and Jain et al. (2017) which indicate that a large number of isolates do not carry the cry2 genes. However, the predominance of the cry2 gene has also been reported (Liang et al., 2011; Lone et al., 2017; Wei et al., 2019).The amplification of the XRE gene in this study revealed that out of five strains of putative strains of $B$. thuringiensis, the gene was detected in four (80\%) when end-point PCR was used which only detects the gene and does not quantify it; while Wei et al. (2019)utilised a real-time PCR which quantifies the number of genes targeted in the amplification of the XRE gene in the detection of Bacillus thuringiensis with a specificity of $94 \%$ achieved. According to report by Wei et al.(2019), the XRE gene is more dominant than the cry2 gene when compared in strains of Bacillus thuringiensis. The primary reason for the efficiency of XRE gene over cry2 gene could be due to the fact that the former is a transcriptional regulator, itregulates the main type of crystal protein production (Wei et al., 2019) and there are currently 78 distinct cry genes families available as biomarkers since several translated cry protein product vary with the different categories of cry genes.

\section{CONCLUSION}

Strains of Bacillus thuringiensis were isolated from various soil types in Zaria, Nigeria. The $X R E$ gene was found to be a more reliable biomarker than the cry2gene in the molecular detection of indigenous strains of Bacillus thuringiensis in the present study. The molecular detection of functional and regulatory genes is a reliable method of studying bacteria with biotechnological applications such as biocontrol.

\section{Acknowledgments}

The authors are grateful to the management of $\mathrm{ABU}$, Zaria for the facilities used during the study.

\section{Author contributions}

AEO, MDA and AHI designed the experiments. AEO conducted the experiments. AEO wrote the manuscript, and MDA and $\mathrm{AHI}$ reviewed the manuscript. 
REFERENCES

Adeyemo, I. A., Abdul-Wahab, S. O., Obadofin, A. A. (2018). Biocontrol Potential of Bacillus thuringiensis Isolated from Soil Samples Against Mosquito Larvae. Ife Journal of Science, 20:2

Bartoszewicz, M. and Marjanska, P. S. (2017). Milk-originated Bacillus cereus sensu lato strains harbouring Bacillus anthracis-like plasmids are genetically and phenotypically diverse. Food Microbiology,64:23-30.

doi: 10.1016/j.fm.2017. 05.009

Bello, A. and Hussaini, I. M. (2017). Detection of Multiple Cry Genes in Bacillus thuringiensis Isolated from Different Soil Typesin Zaria. Microbiology Research Journal International, 20(2):1-6.

Ben-Dov, S. E., Zaritsky, A., Dahan, E., Barak, Z. , Sinai, R., Manasherob, R., Khamraev, A., Troitskaya, E., Dubitsky, A., Berezina, N. and Margalith, Y. (1997). Extended Screening by PCR for Seven Cry group Genes from Fieldcollected Strains of Bacillus thuringiensis. Applied Environmental Microbiology, 63:4883-4890.

Bergey, D. H. (2004). Bergey's Manual of Determinative Bacteriology. Eds., John G. Holt et al., 9th edn. The Williams and Wilkins, Baltimore. 531-532.

Carozzi, N. B., Kramer, V. C., Warren, G. W., Evola, S.and Koziel, M. G. (1991). Prediction of insecticidal activity of Bacillus thuringiensis strains by polymerase chain reaction product profiles. Applied and Environmental Microbiology, 57:3057-3061.

Crickmore, N. (2020). Bacillus thuringiensis toxin nomenclature. Retrieved from http://www.lifesci.sussex. ac. uk/ home/Neil_Crickmore/Bt/toxins2 on 11 th January, 2021.

Crickmore, N., Zeigler, D. R., Schnepf, E., Van Rie, J., Lereclus, D., Baum, J., Bravo, A. and Dean, D. H. (2011). Bacillus thuringiensis toxin nomenclature. Retrieved from http://www.lifesci.sussex. ac. uk/ Home/Neil_Crickmore/Bt on 24thNovember, 2020.

Dharmender, K., Kamla, C. and Boora, K. S. (2008). Characterization of native Bacillus thuringensis strains by PCRRAPD based fingerprinting. Indian Journal of Microbiology, 5:124-127.

Eswarapriya, B., Gopalsamy, B., Kameswari, B., Meera, R. and Devi, P. (2010). Insecticidal activity of Bacillus

UMYU Journal of Microbiology Research thuringiensis IBT-15 strain against Plutella xylostella. International Journal of PharmTech. Research2:20482053.

Fiuza, L. M. (2015). Thuringiensin: a toxin from Bacillus thuringiensis. Bt Research, 6: 1-12. doi:10.5376/bt.2015.06.0004

Frankenhuyzen, K. V. (2009). Insecticidal activity of Bacillus thuringiensis crystal proteins. Journal of Invertebrate Pathology, 101(1):1-16.

Helgason, E., Økstad, O. A., Caugant, D. A., Johansen, H. A., Fouet, A., Mock, M., Hegna, I. and Kolstø, A. B. (2000).Bacillus anthracis, Bacillus cereus, and Bacillus thuringiensis--one species on the basis of genetic evidence. Applied Environmental Microbiology, 66:2627-2630 10.1128/AEM.66.6.2627-2630.2000.

Jain, D., Sunda, S. D., Sanadhya, S., Nath, D. J. and Khandelwal, S. K. (2017). Molecular characterization and PCR-based screening of cry genes from Bacillus thuringiensis strains. Biotechnology, 7:4. doi: 10.1007/s13205-016-0583-7

Kaur, S. (2002). Potential for developing novel Bacillus thuringiensis strains and transgenic crops and theirimplications for Indian agriculture. Agricultural Biotech Net, 4:1-10.

Liang, H., Liu, Y., Zhu, J., Guan, P., Li, S., Wang, S., et al. (2011). Characterization of cry2-type genes of Bacillus thuringiensis strains from soilisolated of Sichuan basin. China.Brazilian Journal of Microbiology.42: 140-146. doi: 10.1590/S1517-83822011000100018

Liu, Y., Lai, Q., Göker, M., Meier-Kolthoff, J. P., Wang, M., Sun, Y., Wang, L. and Shao, Z. (2015). Genomic insights into the taxonomic status of the Bacillus cereus group. Scientific Reports, 5:14082 10.1038/srep14082.PubMed [PubMed: 26373441]

Lone, S. A, Yadav, R., Malik, A.and Padaria, J. C. (2016). Molecular and insecticidal characterizati of Vip3A protein producing Bacillus thuringiensis strains toxic against Helicoverpa armigera (Lepidoptera: noctuidae). Canadian Journal of Microbiology, 62(2):179-190.

Lone, S. A., Malik, A. and Padaria, J. C. (2017). Characterization of lepidopteranspecific cry1 and cry2 gene harbouring native Bacillus thuringiensis isolates toxic against Helicoverpa armigera. Biotechnology Reports, 15:27-32. 
Rasko, D. A., Altherr, M. R., Han, C. S.and Ravel, J. (2005). Genomics of the Bacillus cereus group of organisms. FEMS Microbiology Review,29:303-329. PubMed [PubMed: 15808746]

Roh, J. Y., Choi, J. Y., Li, M. S., Jin, B. R. and Je, Y. H. (2017). Bacillus thuringiensis as a specific, safe, and effective tool for insect pest control. International Journal of Microbiology Biotechnology, 17:547.

Rolle, R. L., Ejiofor, A. O. and Johnson, T. L. (2005). Determination of the plasmid size and location of $d$-endotoxin genes of Bacillus thuringiensis by pulse field gel electrophoresis. African Journal of Biotechnology, 4: 580-585. doi: 10.5897/AJB2005.000-3106

Schünemann, R., Knaak, N. and Fiuza, L. M. (2014). Mode of action and specificity of Bacillus thuringiensis toxins in the control of caterpillars and stink bugs in soybean culture. International Scholarly Research Notices Microbiology, 2:1-12.

Stefani, F. O. P., Bell, T. H., Marchand, C., de la Providencia, I. E., Yassimi, E. I., StArnaaud, M. and Hijri, M. (2015). Culture-Dependent and Independent methods capture different microbial community fractions in Hydrocarboncontaminated soils. PLOSONE, 10(6): 00128272.

Travers, R. S., Martin, P. A. W. and Reichelderfer, C. F. (1987). Selective process for efficient isolation of soil Bacillus species. Applied Environmental Microbiology, 53:1263-1266.

Vilas-Boas, G. T. and Lemos, M. V. F. (2004). Diversity of cry genes and genetic characterization of Bacillus thuringiensis isolated from Brazil. Canadian Journal of Microbiology. 50:605-613.

Wei, S., Chelliah, R., Park, B. J., Kim, S. H., Forghani, F., Cho, M. S., Park, D. S., Jin, Y. G. and Oh, D. H. (2019). Differentiation of Bacillus thuringiensis From Bacillus cereus Group Using a Unique Marker Based on Real-Time PCR. Frontiers in Microbiology, 10:883. doi: 10.3389/fmicb.2019.00883

Willey, J. M., Sherwood, L. M. and Woolverton, C. J. (2008). Prescott, Harley and Klein's microbiology. 6th edition, New York: McGraw-Hill Higher Education. ISBN 978-0073302089. 